\title{
THE EFFECT OF MELATONIN ON THE CATABOLISM OF POLYAMINES IN THE RAT THYMUS DURING THE EXPOSURE TO MICROWAVE RADIATION
}

\author{
Dušan Sokolović1 ${ }^{\text {, Boris Djindjić1,2, Dejan Krstićc }}{ }^{3}$, Vera Marković4, Goran Ristić4, \\ Danka M. Sokolovićs, Mladjan Golubović2, Branka Djordjević1, Momir Dunjić6, \\ Dejan Popović ${ }^{1}$, Tamara Karuntanović1 ${ }^{1}$ Nikola Tatar ${ }^{7}$, Petar Babović 8
}

\begin{abstract}
The toxic effect of microwave radiation (MW) causes the change in the metabolism of polyamines. Polyamines (spermine and spermidine) and their precursor, diamin putrescine, are non-protein nitrogenous bases and they are essential to the function of the cell. Spermine and spermidine are catabolized by the enzyme polyamine oxidase (PAO), while the catabolism of putrescine is under the effect of the diamine oxidase (DAO). The neurohormon melatonin participates in maintaining the normal function of the immune system. The aim of this study was to analyze the effect of melatonin on the catabolism of polyamines in the rat thymus, following the chronic microwave exposure. Wistar rats were divided into four experimental groups: 1) control group, 2) Mel - the animals which were given melatonin daily $(2 \mathrm{mg} / \mathrm{kg}), 3) \mathrm{MW}$ - the animals which were exposed to MW (4h daily), 4) the animals which were exposed to MW and were given melatonin daily. The animals were sacrificed after 20,40 and 60 days of the experiment. There was an increase in the PAO activity and decrease in the DAO activity (already after 20 days) in comparison to the control in the thymus of rats exposed to microwave radiation. There was also a statistically significant positive correlation $(p<0.05)$ between malondialdhehyde levels and the activity of PAO during the MW exposure. A significant decrease in both PAO and DAO activity was found in the thymus of animals exposed to MW and treated with melatonin, in comparison to the irradiated animals not treated with melatonin.
\end{abstract}

Acta Medica Medianae 2018;57(4):14-21. oxydase

Key words: melatonin, microwave radiation, thymus, polyamine oxidase, diamine

\footnotetext{
${ }^{1}$ University of Niš, Faculty of Medicine, Serbia

${ }^{2}$ Clinical Center, Niš, Serbia

${ }^{3}$ University of Niš, Faculty of Occupational Safety, Serbia

${ }^{4}$ University of Niš, Faculty of Electronic Engineering, Serbia

${ }^{5}$ Institute for Blood Transfusion in Niš, Serbia

${ }^{6}$ European University, Novi Sad, Serbia

7 University of Niš, Faculty of Philosophy, Serbia

¿University of Niš, Faculty of Medicine, PhD Student, Niš, Serbia
}

Contact: Dušan Sokolović

Zoran Djindjić blvd. 81, 18000 Niš, Srbija

E-mail: soko@medfak.ni.ac.rs

\section{Introduction}

In recent years, the modern lifestyle has led to the increase in the number of microwave (MW) emitters, not only in the workplace but also in the proximate home environment. The most common MW emitters in our environment are mobile phones, cellular repeaters, WI-FI devices, satellite mobile communication devices, radio transmitters, microwave heating devices and radar facilities. The effects on the human health caused by exposure to electromagnetic fields from mobile phones are not visible in a short period because they are small and cumulative. The independent expert group on mobile phones formed by the British Government has, in its report, recommended a limited mobile phone talk time during the day, relocating radio and cellular repeaters away from populated areas, as well as a limited mobile phone use by children. These recommendations were the result of numerous epidemiological and experimental studies that indicated numerous harmful effects of microwave radiation in animals and humans. It has been proven that MW exposure leads to the promotion of cancer cell growth in the brain, impaired DNA molecule structure, an increase in the leukemia prevalence in children after 2-6 years of radiation exposure, REM sleep cycle disorders, headaches and irritability, as well as a significant disruption of the immune status of the organism. The results of numerous studies have pointed out that the increase in oxidative stress intensity is one of the 
pathogenetic mechanisms involved in the cellular damage after the MW exposure $(1,2)$.

Polyamines spermine and spermidine and their precursor diamine putrescine are non-protein nitrogenous low molecular weight bases present in all living systems (3). An abundance of data from the literature suggests that polyamines are prevalent in almost all tissues and organs, therefore we can say that they are essential to the function of the cell (4). In mammalian cells, polyamines are found in milimolar concentrations, and their highest concentration is spotted in the tissues characterized by an intense protein synthesis (thymus, pancreas, prostate and liver). The importance of polyamines is reflected by their indispensable role in the vital processes of growth, division and cell differentiation (due to the interaction with nucleic acids) (5), as well as their role in regulating the permeability and stability of the cell membrane (by interacting with phospholipids) (6). Recent research on polyamines speak of their antioxidant effects, as well as the inhibitory effect on the lipid peroxidation process (7).

Conversion of L-arginine to L-ornithine by the enzyme arginase is considered as the first step in the polyamine synthesis. In mammalian tissues, initial and rate-limiting reaction in polyamine biosynthesis is decarboxylation of L-ornithine by specific ornithine decarboxylase (ODC) and formation of putrescine. Transfer of the aminopropyl group from 5'-S-methyl5 '-thioadenosine (MTA) is regulated by spermidine synthase. Further condensation of spermidine with another MTA molecule leads to formation of spermine (8). In mammalian cells, biochemical pathway of polyamine catabolism is carried out as an intracellular conversion of polyamine. While spermidine / spermine byosinthesis is an irreversible process, polyamine back-conversion to putrescine is possible and regulated by two enzymes: spermidine / spermine N1 -acetyltransferase (SSAT) and polyamine oxydase (PAO). This interconversion is known as putrescine cycle (4). The first step in the polyamine intercon-version is acetylation of polyamine molecule at $\mathrm{N} 1$ position by SSAT using acetyl-coenzyme A and forming N1-acetyl spermine. It acts as a substrate for PAO in the next step, whereas PAO catalyzes its oxidative deamination producing spermidine, 3-acetamidopro-panal and hydrogen peroxide. These two enzymes are also responsible for back-conversion of spermidine to spermine. An enzyme which catalyzes conversion of spermine back to spermidine without acetylation was discovered in 2002 and it is known today as spermine oxydase (SMO) (9). Amino group of putrescine may further undergo oxydative deamination by diamino oxydase (DAO) producing 4-aminobutanal (gamma-aminobutyraldehyde) which is converted to gamma-aminobutyric acid (GABA).

High activity of PAO and DAO in hepatic, splenic, and thymus tissue shows that these two enzymes have the key role in the maintenance of total content of polyamines in mammalian tissues (10). Polyamine oxydase (EC 1.4.3.4) is a flavin-contraining enzyme with a molecular weight of 60,000 D. To date, there were four PAO isoenzymes discovered, each having different substrate specificity (11). The highest PAO activity is present in the liver, testes, kidneys, and thymus, whereas the preferred substrate is N1-acetyl spermine. High PAO activity is observed in serum of gravid women during the second and third trimester. It is noted that an activity of the PAO is higher in tissues with high polyamine biosynthesis, indicating that PAO might have an important role in polyamine level regulation in mammalian tissues. It is considered that PAO generates putrescine when there is the need to lower the cell content of higher polyamines (spermine and spermidine).

Diamine oxydase (EC 1.4.3.6) is a key enzyme in terminal polyamine catabolism. It catalyzes the oxidative deamination of putrescine, cadaverine, and histamine, consequently producing amino aldehydes, hydrogen peroxide, and ammonia. Optimal $\mathrm{pH}$ for enzyme activity is 7.0-7.4, and half-life is $14 \mathrm{~h}$. Diamino oxydase is a copper-containing enzyme, therefore copper-binding agents, such as diethyldithiocarbamate, inhibit the enzyme activity. Hydrogen peroxide and amino aldehydes produced during polyamine degradation exert cytotoxic properties and may be included in the apoptosis initiation (12).

It has been shown that microwave radiation disrupts the activity of the enzyme ODC and reduces the concentration of ODC mRNA. Exposure to microwave radiation causes a disturbance of polyamine metabolism, which severity depends on the frequency of the radiation used, the exposure time and the type of irradiated tissue. It has been shown that ODC activity decreases 3 to 4 hours after MW exposure in the muscle cells, however, there are results indicating an increase in ODC activity in the brain tissue.

Synthesis of neurohormone melatonin is performed in the pineal gland. The synthesis is controlled by light from the outside environment, which inhibits its biosynthesis. Melatonin mediates the function of numerous hormones and participates in the maintenance of the normal function of the immune system. It shows immunostimulatory effect, prevents the onset of cancer, neurodegenerative diseases and diabetes complications, regulates the level of mRNA for certain proteins (13). Melatonin has significant antioxidant effects in the brain and thymus tissue $(14,15)$. It neutralizes the hydroxyl radical more efficiently than reduced glutathione and mannitol (16), stimulates the mRNA synthesis of superoxidedismutase and glutathione peroxidase (17). It has been shown that it prevents oxidative damage to DNA molecules. The activity of the pineal gland and the secretion of melatonin are not only influenced by external light sources, but are also dependent on the electromagnetic fields. It has been shown that the change in the magnetic field causes a decrease in the secretion of melatonin (18).

\section{Aim}

The aim of this study was to analyze the effect of melatonin on the catabolism of polyamines (by measuring the enzyme activity of DAO and PAO) in the rat thymus after chronic exposure to microwave radiation. 


\section{Material and methods}

\section{Experimental model}

Experiment was performed on white rats of Wistar species, weighing about $200 \mathrm{~g}$, grown at the Institute for Biomedical Research, Faculty of Medicine, Niš. For the purpose of the experiment, an experimental model for the exposure to microwave radiation was created, consisting of a mobile test phone and a PC measuring controller. Using this PC measuring device, the mobile phone is brought into a state of emission that corresponds to the normal mode of operation during a telephone conversation. The mobile test phone was located in a plexiglass box that was placed in the middle of the cage at the floor level. All animals were in plexiglass cages in size $30 \times 40 \times 40 \mathrm{~cm}$. Animals were exposed to microwave radiation in all experimental groups 4 hours a day, then moved to a room without sources of the electromagnetic field. Exposure to microwave radiation lasted for 20, 40 and 60 days.

Laboratory animals were divided into 4 experimental groups: I group (Control) - animals were injected with $1,0 \mathrm{ml}$ of saline intraperitoneally per day; II group (Mel) - animals were injected with melatonin at a dose of $2 \mathrm{mg} / \mathrm{kg}$ body weight intraperitoneally per day; III group (MW) - the animals were exposed to the microwave radiation of the mobile phone 4 hours a day; IV group (MW+Mel) - the animals were exposed to the microwave radiation of the mobile phone 4 hours a day, and 30 minutes before radiation were injected with melatonin at a dose of $2 \mathrm{mg} / \mathrm{kg}$ body weight intraperitoneally per day. Seven animals from each group were successively sacrificed after 20, 40 and 60 days of the experiment.

The animals were sacrificed after the experiment, in ketamine anesthesia ( $2 \mathrm{ml} / \mathrm{kg}$ body weight). After sacrificing experimental animals, the thymus tissue was washed multiple times in a cold isotonic $\mathrm{NaCl}$ solution, immediately frozen at $-20{ }^{\circ} \mathrm{C}$ and kept until homogenization. A $10 \%$ homogenate was then prepared in distilled water at $0{ }^{\circ} \mathrm{C}$ (on ice) using a homogenizer.

\section{Biochemical methods}

Determination of the activity of polyamino oxidase (PAO) and diamino oxidase (DAO). The spectrophotometric determination of the activity of PAO and DAO was performed by measuring the amount of the formed amino aldehyde under the action of these enzymes in the presence of the corresponding substrate (19). Putrescin dihydrochloride was used as a substrate for DAO (20), and spermine tetrahloride was used as a substrate for PAO (21). The reaction takes place in the TRIS- $\mathrm{HCl}$ buffer $\mathrm{pH} 7.2$ for polyamine oxidase and 7.7 for diamine oxidase, with the addition of $0.4 \%$ 3-methyl-2-benzothiazo- lone hydrazone and $0.2 \% \mathrm{FeCl}_{3}$ to give the colored compound. The unit of activity was that amount of enzyme, which causes an increase in optical density by 0,100 at a wavelength of $660 \mathrm{~nm}$ (21). The enzyme activity was expressed in $\mathrm{U} / \mathrm{mg}$ protein.

Determination of malondialdehyde concentration (MDA). The lipid peroxidation intensity in the tissues was measured using the spectrophotometric method based on the use of thiobarbituric acid (TBA), according to the method of Ohkawa et al. (1979). The concentration of MDA, as the final product of lipid peroxidation, was expressed in $\mathrm{nmol} / \mathrm{mg}$ protein, using a molar extinction coefficient for MDA (1.56 $x$ 10-5 $\mathrm{M} \mathrm{cm}^{-1}$ ) (22).

Determination of protein concentration. The amount of total protein in the rat thymus was determined by the Lowry method (1951), with bovine serum albumin as standard (23).

\section{Statistical analysis}

Statistical analysis was done with Excel 7.0 and SPSS 11.0 in the Windows 2000 environment, with results displayed graphically.

\section{Results}

There was an increase in PAO activity in the thymus of rats exposed to microwave radiation, when compared to the control and Mel group ( $\mathrm{MW}_{20}$ vs. Control $_{20}$ and $\mathrm{Mel}_{20} \mathrm{p}<0.05 ; \mathrm{MW}_{40}$ vs. Control 40 and Mel $_{40} \mathrm{p}<0.001 ; \mathrm{MW}_{60}$ vs. Control 60 and Mel $_{60} \mathrm{p}<$ 0.001 ). The application of melatoninin in dose of 2 $\mathrm{mg} / \mathrm{kg}$ body weight to animals exposed to microwave radiation caused a decrease in PAO activity in the thymus tissue, when compared to MW exposed animals not treated with melatonin (MW + $\mathrm{Mel}_{20} \mathrm{vs}$. $\mathrm{MW}_{20} \mathrm{p}<0.05 ; \mathrm{MW}+\mathrm{Mel}_{40}$ vs. $\mathrm{MW}_{40} \mathrm{p}<0.001 ;$ $\mathrm{MW}+\mathrm{Mel}_{60}$ vs. $\left.\mathrm{MW}_{60} \mathrm{p}<0.001\right)($ Graph 1).

A decrease of DAO activity was observed in the thymus tissue of rats exposed to microwave radiation when compared to the control and Mel group $\left(\mathrm{MW}_{20}\right.$ vs. Control 20 and $\mathrm{Mel}_{20} \mathrm{p}<0.05 ; \mathrm{MW}_{40}$ vs. Control $_{40}$ and Mel $_{40} \mathrm{p}<0.001 ; \mathrm{MW}_{60}$ vs. Control 60 and $\left.\mathrm{Mel}_{60} \mathrm{p}<0.001\right)$. The application of melatonin to animals exposed to microwave radiation resulted in a significant decrease of DAO activity in the thymus of $\mathrm{MW}$ exposed animals not treated with melatonin, after 40 days of exposure (MW + Mel $_{40}$ vs. $M W_{40} p<$ $0.05 ; \mathrm{MW}+$ Mel $_{60}$ vs. $\left.\mathrm{MW}_{60} \mathrm{p}<0.05\right)$ (Table 1 ).

Graph 2 shows the correlation between the concentration of malondialdehyde (MDA) and activity of the enzyme PAO in the thymus tissue, during the exposure to microwave radiation. Linear correlation coefficient of $\mathrm{C}=0.61$ indicates that there is a strong and statistically significant positive correlation ( $p<0.05$ ) between the values of the MDA compared to the PAO activity during the exposure to microwave radiation. 


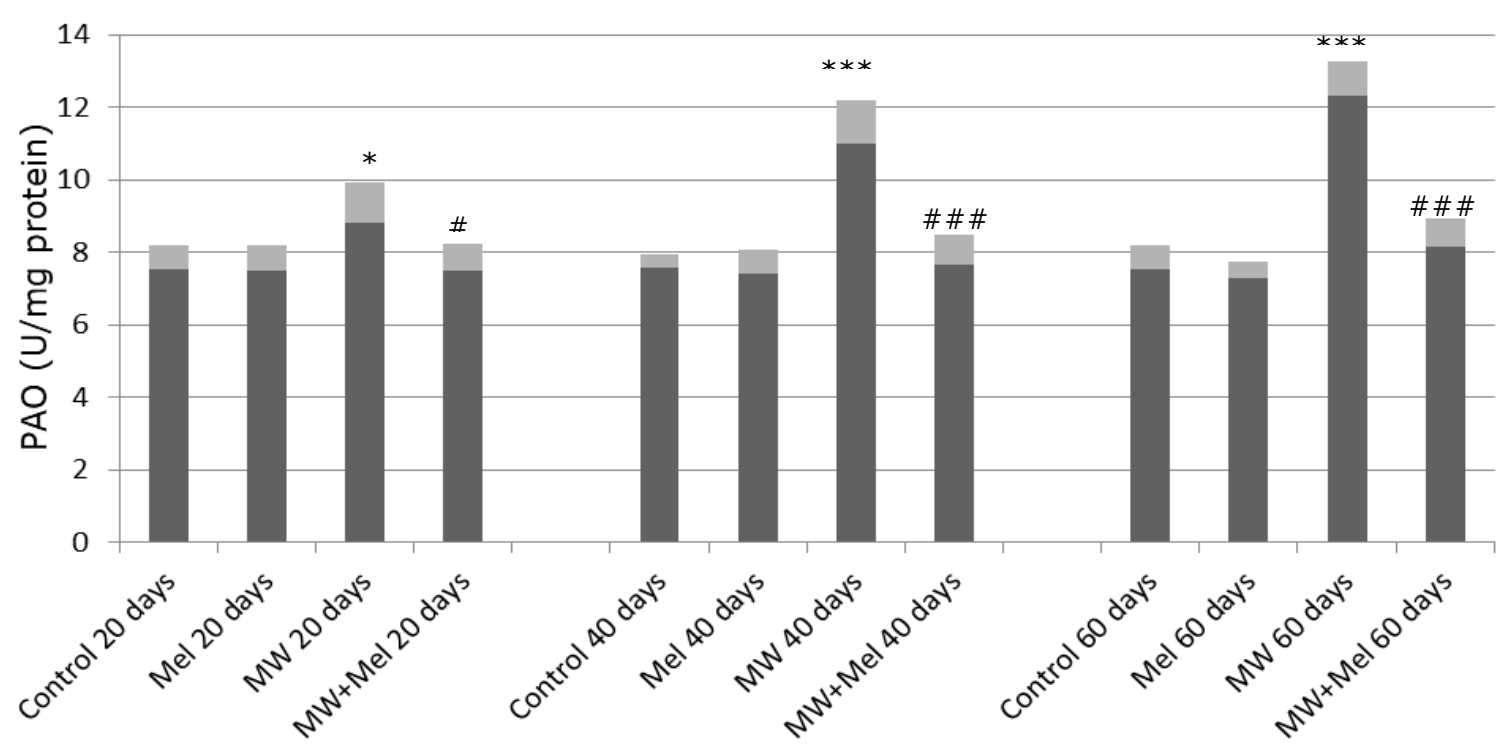

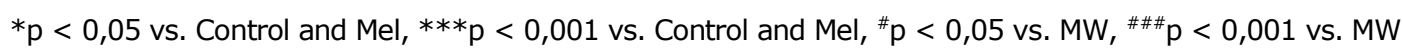

Graph 1. The effect of melatonin and microwave radiation on the enzyme polyamine oxidase (PAO) in rat thymus

Table 1. The effect of melatonin and microwave radiation on the enzyme diamine oxidase (DAO) in rat thymus

\begin{tabular}{||c|c|c|c|c||}
\hline Groups & Control & Mel & MW & MW + Mel \\
\hline \hline 20 days & $9.08 \pm 1.69$ & $8.94 \pm 1.61$ & $7.60 \pm 1.19$ & $6.78 \pm 0.43$ \\
\hline 40 days & $9.42 \pm 1.20$ & $9.18 \pm 1.07$ & $8.09 \pm 0.86^{*}$ & $6.97 \pm 0.55^{\#}$ \\
\hline 60 days & $9.96 \pm 0.90$ & $9.70 \pm 0.83$ & $7.93 \pm 0.87^{* * *}$ & $6.54 \pm 1.52^{\#}$ \\
\hline
\end{tabular}

$* \mathrm{p}<0,05$ vs. Control and Mel, $* * * \mathrm{p}<0,001$ vs. Control and Mel, ${ }^{*} \mathrm{p}<0,05$ vs. MW

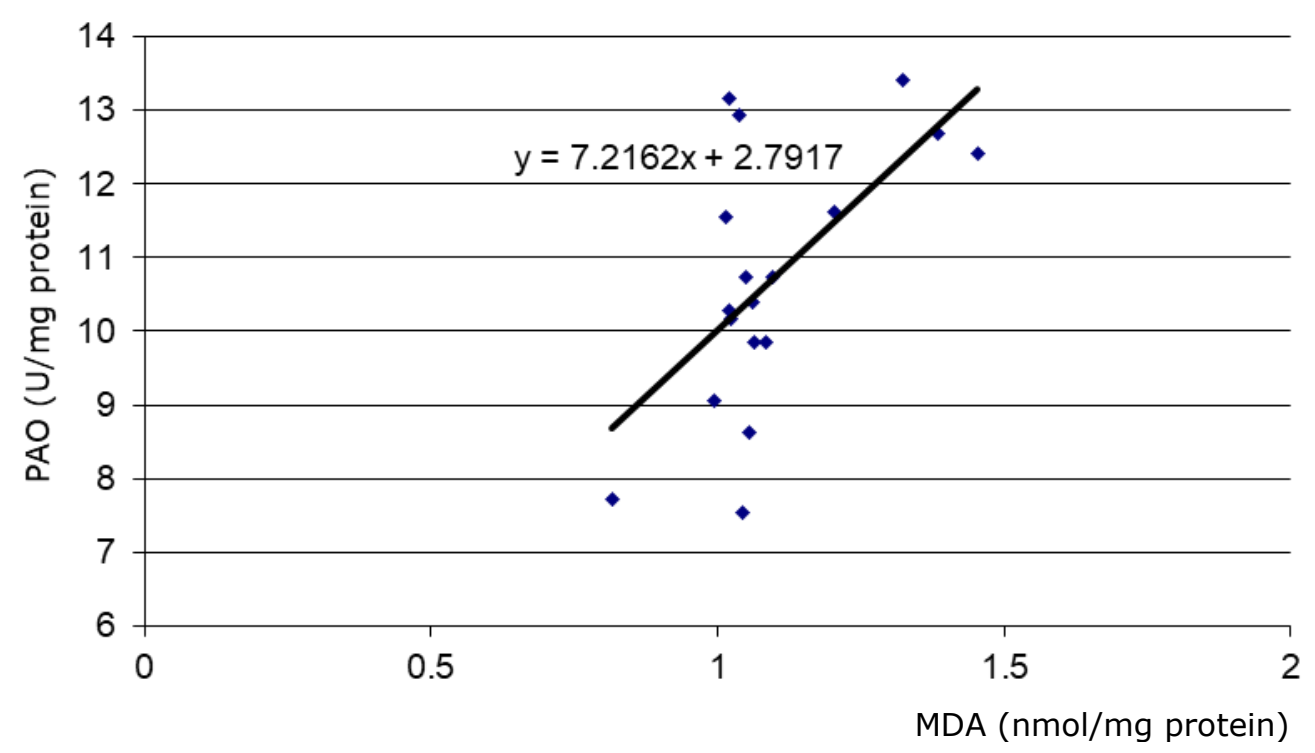

Graph 2. Linear regression between PAO activity (U/mg protein) and MDA ( $\mathrm{nmol} / \mathrm{mg}$ protein) levels in the rat thymus during exposure to microwave radiation 


\section{Discussion}

Polyamine metabolism disturbance in the MWirradiated rat thymus tissue is reflected in intensified catabolism. The exposure of animals to microwave radiation causes a significant, time-dependent increase in PAO activity in the thymus tissue relative to control (Graph 1), which points to intensification of the polyamine interconversion pathway. An intense increase in the PAO activity in the thymus tissue after the exposure to microwave radiation may be a result of polyamine metabolism disturbance that reduces spermine and spermidine (potent cell prolifeferative ability indicators) and increases the amount of putrescine (a biologically less potent indicator of proliferative and regenerative cell ability). This is probably one of the possible mechanisms for cells survival or their controlled transition to the apoptosis process in conditions of exposure to microwave radiation.

Hydrogen peroxide and amino aldehydes formed during the catabolism of spermine and spermidine by the PAO activity have cytotoxic properties and can participate in the initiation of thymocyte apoptosis (12). The combined action of SSAT and PAO in the polyamine acetylation and oxidation leads to the production of $\mathrm{H}_{2} \mathrm{O}_{2}$ which acts as an inducer of the SSAT activity and apoptosis causing a clear death signal. Also, the $\mathrm{H}_{2} \mathrm{O}_{2}$ formed in the process of polyamine catabolism, due to the ability of interaction with $\mathrm{O}_{2}$ - or further degradation in the presence of free iron, can lead to the production of $\mathrm{OH}$ radical the immediate initiator of lipid peroxidation and further increment of this process. The results of the Tadolini study from 1988 indicated the possibility of polyamine role as a modulators of cell damage by free radicals, with the antioxidant effect of polyamine being attributed to the formation of the complex between $\mathrm{Fe}^{2+} /$ spermin/phospholipids, which limits the possibility of the Fenton reaction occurrence and the formation of $\mathrm{OH} \bullet$ (24).

Graph 2 shows the linear regression analysis between the activity of PAO enzymes and levels of malondialdehyde in the thymus tissue of the radiated animals, and it shows a statistically significant positive correlation ratio $(C=0.61)$. This may indicate that the increase in PAO activity significantly contributes to an increase in the MDA level (secondary lipid peroxidation product), in the thymus tissue during microwave radiation exposure. The toxic effects of polyamine catabolism intermediates are related to the MDA concentration (25). It has been proven that 3aminopropion aldehyde, from which MDA may be formed, is created by the action of PAO on spermine and spermidine. The toxicity of MDA as the final product of lipid peroxidation and its ability to modify macromolecules has been confirmed in numerous studies (26). Therefore, it could be expected that the increase in the total concentration of MDA in the thymus of animals exposed to microwave radiation, is partly influenced by the increased catabolism of spermine and spermidine.

Exposure to microwave radiation leads to a significant reduction in the degradation of putrescine by DAO enzyme in thymus tissue (Table 1 ). This can be explained by the striving of thymus cells to preserve the putrescine concentration, as its conversion to GABA leads to the production of toxic reactive oxygen radicals (ROS). Decrease in DAO activity can be considered as a limiting step towards the thymocyte apoptosis. Putrescine has special significance in the regulation of thyroid growth and proliferation in conditions resulting from the action of various immunosuppressants (glucocorticoids and androgens) that lead to a reduction in the amount of polyamines. This is achieved by the interconversion of spermine and spermidine into putrescine (27). On the other hand, putrescine is the most important regulator of $\mathrm{T}$ lymphocyte activity, unlike spermine and spermidine (28). The effect of microwave radiation completely resembles the effects of the immunosuppressant, as there is a decrease in the levels of spermine and spermidine and an increase in the amount of putrescine, followed by an increase in apoptosis and a reduction in proliferation in the thymus.

Spermine and spermidine stabilize chromatin and nuclear enzymes due to their ability to construct complexes with negative groups on proteins and the DNA molecule (29). Therefore, reduction of these polyamines leads to significant changes in the structure of the chromatin and the DNA molecule. It has been shown that spermine and spermidine prevent fragmentation of the DNA, by stabilizing its helix and protecting the thymocytes from apoptotic depletion (30). The effect of microwave radiation that reduces the amount of spermine and spermidine by increasing the activity of PAO significantly contributes to its apoptotic effect.

The results obtained in our experiment show that melatonin exhibits a strong modulatory effect on the disturbed metabolic pathways of the polyamines, in the tissue of the irradiated animals. Administration of melatonin led to a significant reduction in the catabolism of spermine, spermidine and putrescine in the thymus tissue of rats, during exposure to microwave radiation. This can be explained by the striving of thymus cells to preserve the concentration of spermine, spermidine and putrescine, which have been shown to have significant protective effects. It has been proven that polyamines participate in processes of growth, division and differentiation of cells, and therefore in regenerative, reparative and proliferative processes. In addition, spermine, spermidine and putrescine might be important for the stabilization of the cell membrane, antioxidative and antiapoptotic activity (31). Reduction of PAO and DAO activity aims to the growth of polyamine pools and the preservation of the regenerative and proliferative ability of the thymus cells, as demonstrated in this study.

\section{Conclusion}

By analyzing the obtained experimental results, it can be concluded that in condition of chronic exposure to microwave radiation, there are significant changes in the catabolism of polyamines in the thymus tissue of rats. The application of melatonin led to a normalization of the disturbed metabolism of spermine and spermidine (by lowering the activity of 
polyamine oxidase), as well as the additional increase in the level of putrescine (by lowering the activity of diamine oxidase) in the irradiated animals.

\section{Acknowledgment}

This work was funded by the Ministry of Education, Science and Technological Development of Serbia (grant No. III 43012).
1. Sokolovic D, Djordjevic B, Kocic G, Jevtovic Stoimenov $T$, Stanojkovic $Z$, Sokolovic DM et al. The effects of melatonin on oxidative stress parameters and DNA fragmentation in testicular tissue of rats exposed to microwave radiation. Adv Clin Exp Med 2015; 24 (3): 429-36. [CrossRef][PubMed]

2. Köylü $H$, Mollaoglu $H$, Ozguner $F$, Naziroglu $M$, Delibas N. Melatonin modulates $900 \mathrm{Mhz}$ microwave-induced lipid peroxidation changes in rat brain. Toxicol Ind Health 2006; 22(5):211-6. [CrossRef][PubMed]

3. Tabor $\mathrm{H}$, Tabor $\mathrm{CW}$. Spermidine, spermine and related amines. Pharmacol Rev 1964; 16:245-300. [CrossRef][PubMed]

4. Thomas T, Thomas TJ. Polyamines in cell growth and cell death: molecular mechanisms and therapeutic applications. Cell Mol Life Sci 2001; 58(2):244-58. [CrossRef][PubMed]

5. Xiao L, Swank RA, Matthews HR. Photoaffinity polyamines: sequence specific interactions with DNA. Nucleic Acids Res 1991; 19(13):3701-8. [CrossRef]

6. Schuber F. Influence of polyamines on membrane functions. Biochem J 1989; 260(1):1-10.

[CrossRef][PubMed]

7. Gaboriau F, Vaultier M, Moulinoux JP, Delcros JG. Antioxidative properties of natural polyamines and dimethylsilane analogues. Redox Rep 2005; 10(1):9-18. [CrossRef][PubMed]

8. Williams-Ashman HG, Seidenfeld J, Galletti P. Trends in the biochemical pharmacology of $5^{\prime}$-deoxy-5'-methylthioadenosine. Biochem Pharmacol 1982; 31(3): 277-88. [CrossRef][PubMed]
9. Vujcic S, Diegelman P, Bacchi CJ, Kramer DL, Porter CW. Identification and characterization of a novel flavin-containing spermine oxidase of mammalian cell orgin. Biochem J 2002; 367(Pt 3):665-75. [CrossRef][PubMed]

10. Bjelakovic G, Kocic G, Pavlovic D, Nikolic J, Stojanovic I, Bjelakovic GB et al. Effects of folic acid on polyamine concentrations and polyamine oxidase activity in regenerating rat liver. Pteridines 2003; 14(4):10913. [CrossRef]

11. Bolkenius FN, Seiler N. Acetylderivates as intermediates in polyamine catabolism. Int J Biochem 1981; 13 (3):287-92. [CrossRef][PubMed]

12. Parchment RE, Pierce GB. Polyamine oxidation, programmed cell death, and regulation of melanoma in the murine embryonic limb. Cancer Res 1989; 49(23): 6680-86. [CrossRef][PubMed]

13. Baydas G, Canatan H, Turkoglu A. Comparative analysis of the protective effects of melatonin and vitamin $\mathrm{E}$ on streptozocin-induced diabetes mellitus. J Pineal Res 2002; 32(4):225-30. [CrossRef][PubMed]

14. Sokolovic D, Djindjic B, Nikolic J, Bjelakovic G, Pavlovic $D$, Kocic $G$ et al. Melatonin reduces oxidative stress induced by chronic exposure of microwave radiation from mobile phones in rat brain. J Radiat Res 2008; 49(6):579-86. [CrossRef][PubMed]

15. Sokolovic D, Djordjevic B, Kocic G, Veljkovic A, Marinkovic $M$, Basic J et al. Melatonin protects rat thymus against oxidative stress caused by exposure to microwaves and modulates proliferation/apoptosis of thymocytes. Gen Physiol Biophys 2013; 32(1):79-90. [CrossRef][PubMed] 
16. Poeggeler B, Reiter RJ, Tan DX, Chen LD, Manchester LC. Melatonin, hydroxyl radical-mediated oxidative damage, and aging: a hypothesis. J Pineal Res 1993; 14(4):151-68. [CrossRef][PubMed]

17. Antolín I, Rodríguez C, Saínz RM, Mayo JC, Uría $H$, Kotler ML et al. Neurohormone melatonin prevents cell damage: effect on gene expression for antioxidant enzymes. FASEB J 1996; 10(8):882-90. [CrossRef][PubMed]

18. Brendel $H$, Niehaus $M$, Lerchl $A$. Direct suppressive effects of weak magnetic fields $(50 \mathrm{~Hz}$ and $162 / 3 \mathrm{~Hz}$ ) on melatonin synthesis in the pineal gland of Djungarian hamsters (Phodopus sungorus). J Pineal Res 2000; 29(4):228-33. [CrossRef][PubMed]

19. Bachrach $U$, Reches B. Enzymatic assay for spermine and spermidine. Anal Biochem 1966; 17(1):38-48. [CrossRef][PubMed]

20. Quash G, Calogero H, Fossar N, Ferdinand A, Taylor D. Modification of diamine oxidase activity in vitro by metabolites of asparagine and differences in asparagine decarboxylation in normal and virus-transformed baby hamster kidney cells. Biochem J 1976; 157(3): 599-608. [CrossRef][PubMed]

21. Quash G, Gresland L, Delain E, Huppert J. Antipolyamine antibodies and cell lysis. The inhibitory effect of putrescine. Exp Cell Res 1972; 75(2):363-8. [CrossRef][PubMed]

22. Ohkawa H, Ohishi N, Yagi K. Assay for lipid peroxides in animal tissues by thiobarbituric acid reaction. Anal Biochem 1979; 95(2):351-58. [CrossRef][PubMed]

23. Lowry OH, Rosebrough NJ, Farr AL, Randall RJ. Protein measurement with the Folin phenol reagent. J Biol Chem 1951; 193(1):265-75. [CrossRef][PubMed]
24. Tadolini B. Polyamine inhibition of lipid peroxidation. The influence of polyamines on iron oxidation in the presence of compounds mimicking phospholipid polar heads. Biochem J 1988; 249(1):33-36. [PubMed]

25. Quash G, Taylor DR. Serum $\beta$-aminopropionaldehyde: Identification and origin. Clin Chim Acta 1970; 30(1): 17-23. [CrossRef]

26. Nair V, Cooper CS, Vietti DE, Turner GA. The chemistry of lipid peroxidation metabolites: crosslinking reactions of malondialdehyde. Lipids 1986; 21 (1):610. [CrossRef][PubMed]

27. Ferioli ME, Pinotti O, Pirona L. Gender-related differences in polyamine oxidase activity in rat tissues. Amino Acids 1999; 17(2):139-48. [CrossRef][PubMed]

28. Seiler N, Atanassov CL. The natural polyamines and the immune system. In: Jucker $\mathrm{E}$, editor. Progress in Drug Research. Basel: Birkhauser 1994. p. 87-141. [CrossRef]

29. Heby O, Persson L. Molecular genetics of polyamine synthesis in eukaryotic cells. Trends Biochem Sci 1990; 15(4):153-8. [CrossRef][PubMed]

30. Redman C, Xu MJ, Peng YM, Scott JA, Payne C, Clark $L C$, et al. Involvement of polyamines in selenomethionine induced apoptosis and mitotic alterations in human tumor cells. Carcinogenesis 1997; 18(6):1195202. [CrossRef][PubMed]

31. Hu RH, Pegg AE. Rapid induction of apoptosis by deregulated uptake of polyamine analogues. Biochem J 1997; 328(Pt 1):307-16. [CrossRef][PubMed] 


\title{
EFEKAT MELATONINA NA KATABOLIZAM POLIAMINA U TIMUSU PACOVA TOKOM IZLAGANJA MIKROTALASNOM ZRAČENJU
}

\author{
Dušan Sokolović ${ }^{1}$, Boris Đinđić1, ${ }^{1}$, Dejan Krstić3 ${ }^{3}$, Vera Marković4, Goran Ristić4, \\ Danka M. Sokolović5, Mlađan Golubović2, Branka Đorđević1, Momir Dunjić6, \\ Dejan Popović ${ }^{1}$, Tamara Karuntanović1, Nikola Tatar7, Petar Babović ${ }^{8}$
}

\author{
${ }^{1}$ Univerzitet u Nišu, Medicinski fakultet, Srbija \\ ${ }^{2}$ Klinički centar Niš, Srbija \\ ${ }^{3}$ Univerzitet u Nišu, Fakultet zaštite na radu, Srbija \\ ${ }^{4}$ Univerzitet u Nišu, Elektronski fakultet, Srbija \\ ${ }^{5}$ Institut za transfuziju krvi, Niš, Srbija \\ ${ }^{6}$ Evropski Univerzitet, Novi Sad, Srbija \\ 7Univerzitet u Nišu, Filozofski fakultet, Niš, Srbija \\ ${ }^{8}$ Univerzitet u Nišu, Medicinski fakultet, Student doktorskih studija, Niš, Srbija
}

Kontakt: Dušan Sokolović

Bul. Dr Zoran Đinđić 81,18000 Niš, Srbija

E-mail: soko@medfak.ni.ac.rs

Toksično dejstvo mikrotalasnog zračenja (MW) utiče na promenu metabolizma poliamina. Poliamini (spermin i spermidin) i njihov prekursor diamin putrescin, predstavljaju neproteinske azotne baze i oni su esencijalni za život ćelije. Katabolizam spermina i spermidina obavlja se dejstvom enzima poliamin oksidaze (PAO), a putrescina diamin oksidaze (DAO).Neurohormon melatonin učestvuje u održavanju normalne funkcije imunog sistema. Cilj ovog istraživanja bio je da se analizira efekat melatonina na katabolizam poliamina u timusu pacova, nakon hronične ekspozicije mikrotalasnom zračenju. Wistar pacovi su bili podeljeni u četiri eksperimentalne grupe: 1) kontrola, 2) Mel -životinjama je svakodnevno davan melatonin (2mg/kg), 3) MW -životinje su izlagane MW (4h/dnevno), 4) MW+Mel -pacovi kojima je aplikovan melatonin izlagani su MW. Životinje su žrtvovane nakon 20, 40 i 60 dana eksperimenta. U timusu pacova koji su izlagani mikrotalasnom zračenju došlo je do porasta aktivnosti PAO i sniženja aktivnosti DAO (već nakon 20 dana) u odnosu na kontrolu. Postoji i statistički značajna pozitivna korelacija $(p<0,05)$ između nivoa malondialdehida i aktivnosti PAO, u toku izlaganja MW. Kod životinja koje su izlagane MW i kojima je aplikovan melatonin, došlo je do značajnog sniženja aktivnosti PAO i DAO u tkivu timusa, u odnosu na ozračene životinje koje nisu tretirane melatoninom.

Acta Medica Medianae 2018;57(4):14-21. oksidaza

Ključne reči: melatonin, mikrotalasno zračenje, timus, poliamin oksidaza, diamin 